\title{
COLAPSO E DETERMINISMO ESCALAR EM TEMPOS PANDÊMICOS: REFLEXÕES PRELIMINARES SOBRE A CASA, O "ISOLAMENTO SOCIAL" E O DÉFICIT HABITACIONAL
}

\author{
Scalar collapse and scalar determinism in pandemic times: \\ preliminary remarks on house, "social isolation" and housing deficit \\ Colapso y determinismo escalar en tiempos pandémicos: \\ reflexiones provisorias sobre la casa, el "aislamiento social" y el deficit de vivienda \\ Matheus da Silveira Grandi \\ Professor Adjunto do DGEO/FFP/UERJ \\ mtsgrandi@gmail.com
}

Artigo enviado para publicação em 28/04/2020 e aceito em 30/04/2020

DOI: $10.12957 /$ tamoios.2020.50511

\section{Resumo}

O texto consiste em um exercício metodológico experimental que visa lançar um olhar escalar introdutório sobre a pandemia de covid-19 a partir de reflexões sobre como as recomendações sanitárias de "isolamento social" influenciam na percepção do recorte espacial da casa enquanto uma escala geográfica significativa nestes nossos tempos pandêmicos, considerando, sobretudo, as desigualdades que condicionam a experiência dos sujeitos com tal escala.

Palavras-chave: Pandemia; Covid-19; Escala geográfica; Casa; Déficit habitacional.

\begin{abstract}
This text consists of an experimental methodological exercise that aims to launch an introductory scalar look at the covid-19 pandemic by reflecting on how sanitary recommendations of "social isolation" influence the perception of the space of the house as a meaningful geographical scale in these pandemic times, considering above all the inequalities that impacts the experience of subjects with such scale.
\end{abstract}

Keywords: Pandemics; Covid-19; Geographical scale; House; Housing deficit

\section{Resumen}

El texto consiste en un ejercicio metodológico experimental que tiene por objeto lanzar una mirada escalar introductoria a la pandemia de covid-19 utilizándose de reflexiones sobre cómo las recomendaciones sanitarias de "aislamiento social" influyen en la percepción del corte espacial de la casa como una escala geográfica significativa en nuestros tiempos pandémicos, considerando sobre todo las desigualdades que condicionan la experiencia de los sujetos con dicha escala.

Palabras-clave: Pandemia; Covid-19; Escalas geograficas; Casa; Deficit de vivienda 


\section{Introdução}

Dia 24 de abril de 2020, trigésimo quinto dia de quarentena em um bairro de classe média da zona norte do Rio de Janeiro. Mais especificamente: uma casa com quintal e acesso à infraestrutura urbana básica, além de entregas domiciliares de mantimentos e outras necessidades; núcleo familiar com seis pessoas contando a presença de três crianças, duas intermitentes e uma imaginária, um casal em relação aberta, dois adultos conturbados, uma gata e mosquitos. Muitos mosquitos. A descrição poderia continuar infinitamente e, embora efetivamente carecesse ser acompanhada por análises mais detidas, dariam ao menos um pontapé inicial à tentativa de expressar o caráter situado destas linhas, ecoando a preocupação de muitas pensadoras e pensadores que, sob inspiração das teorias feministas, decoloniais e pós-estruturalistas, vêm destacando a necessidade acadêmica de se reconhecer a posicionalidade dos saberes como maneira de contribuir com a rigorosidade metodológica das reflexões científicas (SANTOS, 2008; HARAWAY, 1995; QUILOMBA, 2019).

A importância de ressaltar esse aspecto parece ampliada em tempos como os quais atravessamos desde pouco antes de 11 de março deste ano de 2020, data na qual a Organização Mundial de Saúde (OMS) declarou enquanto pandêmica a situação de difusão global do vírus SARS-CoV-2 ${ }^{1}$, patógeno causador da doença nomeada covid-19 (acrônimo para coronavirus disease 2019) que já afligia desde dezembro pessoas de Wuhan, cidade com cerca de 10 milhões de habitantes da província chinesa de Hubei ${ }^{2}$. Tais posições das quais falamos compõem o campo de forças que nos confere pontos de equilíbrio obrigatoriamente específicos desde os quais dotamos de sentido nossa experiência pandêmica. Nesses termos, o que pensar sobre estes tempos pandêmicos com cerca de um mês de quarentena experienciada de forma a ter em conta as diferentes condições materiais, simbólicas, emocionais e políticas que coexistem nesse "agora"?

Particularmente me interessa olhar para os recursos e caminhos disponíveis para se pensar sobre este momento desde uma perspectiva sensível à dimensão escalar de sua espacialidade. Vale estabelecer, portanto, as bases conceituais a partir das quais estas reflexões se constroem. Entendo aqui por dimensão escalar da espacialidade aquela responsável por estabelecer, por um lado, os limites e características dos recortes espaciais contínuos tomados como referências e, por outro, as maneiras como tais unidades espaciais se articulam de forma a compor uma totalidade espacial. Trata-se, portanto, daquela dimensão que define unidades espaciais contínuas e as articula em totalidades recorrendo a relações em rede, conforme já trabalhado em outros textos ${ }^{3}$. Como uma dimensão da espacialidade, as escalaridades desempenham o importante papel de guiar nossa interpretação a respeito dos aspectos que indicam uma coesão espacial contígua e daquelas conexões estabelecidas entre os recortes espaciais. A maneira como organizamos, damos sentido e explicamos o mundo, portanto, depende diretamente dessa dimensão da espacialidade.

Tomemos inicialmente algumas produções que já circulam entre nós e que se propõem a refletir sobre estes tempos pandêmicos. É possível perceber que dentre elas há aquelas que mantém seus focos nas características dessa emergência sanitária mundial que se vinculam às dinâmicas globais de acumulação de capital, incluindo aí os fluxos de indivíduos (sobretudo membros de elites econômicas e políticas), por exemplo ${ }^{4}$. Há também aquelas que lançam um olhar mais regionalizado sobre o momento, empreendendo leituras sobre e a partir da chegada do SARS-CoV-2 tomando como recortes analíticos e empíricos diferentes continentes, países ou espaços intranacionais ${ }^{5}$. Outras destacam os desdobramentos da pandemia em meio a parcelas específicas da população, sobretudo aquelas em situação de vulnerabilidade em relação à covid-19 como 
decorrência de condições socioespaciais precárias prévias à pandemia ${ }^{6}$. Note-se que entre esse último conjunto de colocações estão aquelas que desenvolvem as reflexões a partir de construções conceituais que tomam diferentes recortes espaciais como referência, indo da periferia e da favela aos corpos-território e "corpos sensíveis".

$\mathrm{Na}$ busca por somar elementos a essas importantes contribuições feitas com o intuito de construir um sentido espacial dos tempos pandêmicos que vivemos, parto do ímpeto de exercitar uma leitura escalar possível sobre esse evento para, inicialmente, destacar uma preocupação que considero importante termos ao desenvolvermos nossas reflexões - e que, a rigor, também serve para a análise de outros acontecimentos. Obviamente não é o objetivo aqui utilizar tal preocupação para realizar juízos a respeito das instigantes reflexões espacialmente sensíveis já tornadas públicas (sobretudo do campo acadêmico da Geografia), mas sim de incorporar a esse conjunto de reflexões mais algumas linhas. Considero crucial, portanto, atentarmos aos riscos de incorrermos em determinismos escalares em nossos escritos, em meio aos quais podemos acabar por assumir aprioristicamente que “(...) os aspectos encontrados em certas escalas determinariam as características das relações desenroladas em outras - ainda que a escala das relações que servem de referência inicial para esse espelhamento possa ser ora o 'global', ora o 'local', ora outro recorte espacial qualquer." (GRANDI, 2015, p. 119120) Isso diz respeito diretamente aos pressupostos teórico-epistemológicos de nossas leituras que influenciam a compreensão e explicação do desenvolvimento dos eventos que nos dedicamos a estudar.

Empiricamente falando, no entanto, é certo que não se pode assumir que as dinâmicas ocorridas nos diferentes espaços possuem a mesma importância para o desenrolar das situações. A diferenciação espacial e as maneiras como ela influencia as dinâmicas do exercício do poder são aspectos centrais para a politização dos processos sociais, o que só reforça o caráter não apenas epistemológico, mas profundamente político da dimensão escalar da espacialidade. $\mathrm{O}$ alerta feito em meio ao debate teórico-conceitual sobre as escalas geográficas, porém, indica que há riscos metodológicos e políticos quando assumimos a priori que as relações estabelecidas em uma escala predeterminariam aquelas ocorridas em outras. Um dos riscos metodológicos é que, por estarmos buscando a influência de um determinado recorte espacial em um dado processo, terminemos por nos cegar para outros recortes que talvez desempenhem papeis ainda mais importantes no processo investigado do que aquele previamente eleito por nós. É possível vermos esse problema, por exemplo, em algumas pesquisas que, apesar de preocupadas com a chamada política de escalas, conferem mais atenção às escalas geográficas do que aos processos socioespaciais que se desenrolam e as constituem (HEROD E WRIGHT, 2002). O determinismo escalar, nesses casos, anda de mãos dadas com a reificação das escalas geográficas, responsável por apartar esses recortes espaciais das práticas que os constituem. "As escalas continuariam sendo vistas, portanto, basicamente como um esqueleto, uma estrutura de resoluções espaciais previamente existentes através e no interior das quais a vida social se daria." (GRANDI, 2015, p. 126)

É em meio a esse mesmo debate sobre a escalaridade das relações socioespaciais onde quero buscar inspiração para pensar sobre esse momento de pandemia. Nessas reflexões há quem ressalte a diferença fundamental entre perspectivas que consideram que as ações sociais ocorrem no ou através do espaço (mais arriscadas, portanto, a reificar as escalas e incorrer em determinismos escalares) e aquelas abordagens que partem da concepção de que as práticas sociais efetivamente produzem o espaço ${ }^{7}$. Ao invés de buscar o caráter político das escalas, portanto, meu intento será explicitar alguns dos elementos que conferem conteúdo escalar às práticas políticas. Essa tentativa se baseia em quatro elementos-chave ${ }^{8}$ : um olhar crítico diante da ideia de 
política de escalas; o interesse pelos usos estratégicos que os atores sociais fazem das escalas; a influência que escalas e arranjos escalares prévios exercem sobre os processos; e a possibilidade de emergência de novos arranjos escalares a partir do contato entre as estruturas escalares herdadas e os processos políticos que se desenvolvem. Estas páginas, portanto, fazem parte de um exercício metodológico experimental que visa lançar um olhar escalar introdutório sobre a pandemia de covid-19 a partir de reflexões sobre como as recomendações sanitárias de "isolamento social" influenciam na percepção do recorte espacial da casa enquanto uma escala geográfica significativa nestes nossos tempos pandêmicos.

Se o foco das reflexões deve estar nos processos e não nos recortes espaciais, quais processos poderiam servir como um guia possível para pensar sobre a escalaridade da pandemia de covid-19? Minha aposta é buscar dentre aqueles que ganhem maior destaque no espaço-tempo cotidiano, dada tanto a sua importância na construção dos sentidos concretos a respeito das experiências vividas quanto o fato de que, ao partir de tal recorte espaço-temporal, também fica sublinhada a preocupação com a posicionalidade dessas reflexões. Em consequência dessa escolha, portanto, o questionamento automático é: desde onde experienciamos esta pandemia? Como esses locais (espaciais, sociais e políticos) influenciam nossas interpretações a respeito dessas diferentes experiências? E qual exemplo de processo poderíamos pinçar desse mundo da vida?

Um elemento reforçado por muitos dos textos já publicizados no campo da Geografia é a explícita desigualdade do impacto da difusão do SARS-CoV-2, uma vez que ela atinge mundos já estruturados de maneiras desiguais. Essa desigualdade é captada a partir dos estímulos do cotidiano e enquadrada fazendo referência a aspectos globais dominantes (capitalismo, globalização etc.). O argumento de que estaríamos "todos no mesmo barco" - já desconstruído há tempos em diferentes debates a respeito da crise climática que enfrentamos, por exemplo - tem sua hipocrisia revelada quando tais trabalhos sublinham e ecoam as denúncias e a publicização das disparidades de classe, gênero, etnia, raça, idade, orientação do desejo e condições físicas, dentre tantas outras, que atravessam esse e outros momentos. As expressões dessas desigualdades são arremessadas contra nossos sentidos também em nosso dia a dia pandêmico a cada pessoa que precisa manter sua jornada de trabalho cotidiana (por convocação ou por subsistência), mas também com cada uma que usufrui das condições para isolar-se em meio ao luxo e a serviçais, cada situação de violência doméstica de gênero ou infantil, cada caso de racismo reforçado pela mero cumprimento de medidas sanitárias básicas como a circulação com máscaras de proteção individual.

As condições concretas das diferentes parcelas da população de adotarem os cuidados preventivos recomendados por autoridades sanitárias internacionais são elementos centrais, portanto, na avaliação da desigualdade sócio-espacial que se expressa também nesse período. Quais indicações são essas? Considerando a influência das condições de adoção das indicações sanitárias na experiência que vimos tendo com a percepção da desigualdade sócio-espacial nesse momento, talvez seja melhor nos perguntarmos: quais são as indicações de cuidados preventivos ao contágio pelo SARSCoV-2 mais comumente divulgadas? Em geral trata-se daquelas difundidas pelas autoridades sanitárias nacionais e internacionais, cuja maior referência segue sendo a Organização Mundial de Saúde. A OMS define as ações de saúde pública e social como sendo de cinco tipos (OMS, 2020c): medidas básicas de proteção individual (medidas de higiene - higienização das mãos e etiqueta respiratória —, uso de máscara por pessoas sintomáticas, isolamento e tratamento de indivíduos doentes ou com suspeita de contágio e quarentena de pessoas com histórico de contato com indivíduos contaminados); 
medidas ambientais; medidas de distanciamento físico (manutenção de distanciamento individual de ao menos um metro, restrição de aglomerações); medidas ligadas a viagens (identificação, entrevista, registro, isolamento, cuidado e encaminhamento de viajantes doentes [OMS, 2020d]); e medidas de larga escala — “(...) incluindo restrições de movimento, fechamento de escolas e negócios, quarentena de áreas geográficas e restrições de viagens internacionais." (OMS, 2020c, p. 1) ${ }^{9}$ Aqui vale mais um esclarecimento conceitual, agora com base nas definições da $\mathrm{OMS}^{10}$, a respeito das diferenças entre o isolamento, o distanciamento social e a quarentena. É certo que todos têm como objetivo geral a redução da dispersão do vírus em meio a uma determinada população. No entanto, o termo "isolamento" se refere ao processo de separar um indivíduo comprovadamente infectado dos demais. O distanciamento social, por sua vez, diz respeito à manutenção de uma distância mínima de segurança entre as pessoas visando evitar um eventual contágio propiciado pela proximidade física. A quarentena, por fim, trata-se da “(...) restrição de movimento ou separação do resto da população de pessoas saudáveis que podem ter sido expostas ao vírus, com o objetivo de monitorar seus sintomas e assegurar a detecção precoce dos casos." (OMS, 2020e, p. 1) $)^{11}$

Algumas medidas de proteção individual, distanciamento físico e de larga escala têm sido crescentemente questionadas publicamente no contexto brasileiro atual. Além das pressões de entidades patronais de certas regiões do país para que algumas medidas sejam flexibilizadas ${ }^{12}$ — notadamente aquelas com alegado maior impacto sobre o setor produtivo - alguns dos mais notórios questionamentos têm sido declamados pelo atual chefe do poder executivo nacional, contrariando de forma surpreendente os posicionamentos e recomendações de chefes de Estado e autoridades sanitárias de mais de 150 países (além da ONU, OMS e UNESCO) ${ }^{13}$. Dentre as medidas mais afrontadas estão aquelas popularmente conhecidas como de isolamento social e as quarentenas implementadas em diferentes cidades e estados do Brasil — termos que assumem sentidos similares na maior parte da grande imprensa e nos meios populares.

Uma vez que, como já mencionado, um dos elementos centrais na constatação das desigualdades que cortam a atual pandemia de covid-19 é a possibilidade de adoção das medidas propostas pelas entidades sanitárias internacionais; e considerando a relevância que esse processo ganha nas experiências que temos nesses tempos - podendo aderir a essas recomendações ou não; partirei do processo popularmente chamado de "isolamento social" (termo que tem sido utilizado para referir-se a uma mescla de compreensões flexíveis a respeito de duas medidas: a quarentena e o distanciamento social) para exercitar uma possibilidade de olhar escalar sobre estes tempos.

\section{Sobre a escalaridade do "isolamento social"}

Convivemos atualmente com recomendações incisivas de adoção de medidas de restrição de circulação e mobilidade física das quais decorrem, em algumas diversas cidades e estados brasileiros, decretos estatais obrigando o fechamento temporário de determinados estabelecimentos públicos e privados, a diminuição da oferta de transporte público e a consequente redução das interações sociais presenciais. Tais ações são indicadas por diversas autoridades de saúde pública internacionais e de diferentes países como sendo de grande importância para a redução dos riscos de espraiamento do SARSCoV-2, de contágio com covid-19, de complicações derivadas dessa infecção, da busca por atendimento nos sistemas de saúde pública ou privada e, então, de sua sobrecarga e colapso - o que impactaria também o atendimento de diversas outras demandas atendidas por esses sistemas. Trata-se de ações preventivas, portanto, fundamentais à 
manutenção da rede de assistência à saúde da população em geral, como bem reforçado por diferentes agentes há mais de um mês no país.

Tais medidas são aglutinadas frequentemente sob a expressão "isolamento social". Do ponto de vista socioespacial, porém, tal expressão guarda incongruências que permitem, ao mesmo tempo, vislumbrar algumas das manifestações das disparidades sociais sob as quais se assenta a atual emergência sanitária global e, por outro lado, destacar alguns aspectos explicitamente escalares desse momento.

A rigor, portanto, há de se reconhecer que as medidas propagadas não configuram de fato o incentivo ou a expressão de alguma forma de "isolamento social". Primeiramente, como outros autores já se anteciparam em afirmar, o espraiamento mundial da covid-19 traz em sua trajetória as marcas da globalização e do sistema que ofereceram as circunstâncias ideais para que uma mutação viral ganhasse o mundo sob a forma de um novo patógeno ${ }^{14}$. Seu espraiamento desestabilizou os ciclos produtivos globais e suas cadeias produtivas, deixando entrever a falsidade do "pêndulo" políticoeconômico entre keynesianos e neoliberais (PORTO-GONÇALVES, 2020a) e nos permitindo focar, mais uma vez, no eixo civilizatório ao redor do qual essas posições oscilam. As análises preliminares sobre sua difusão pelo Brasil, por sua vez, também explicitam as formas como a estrutura social desigual do país é refletida nos padrões espaciais desenhados pelos casos de contágio - vide o papel que as elites e parcela importante da classe média tiveram na importação e espalhamento do vírus pelo Brasil, semelhante ao restante do mundo ${ }^{15}$. Mesmo a recorrência já apontada nas reflexões mais recentes sobre o impacto socialmente diferenciado desta pandemia serve para aterrar a estrutural "desigual redistribuição de vulnerabilidades" (MBEMBE, 2020). Se a globalização marca a difusão do SARS-CoV-2 e, por sua vez, enquanto atualização contemporânea da moderno-colonialidade também é marcada pela intensificação desigual de determinados fluxos globais, a simples existência da pandemia (e seus desdobramentos cotidianos, como a adoção de novos hábitos, temporários ou permanentes) já indica, então, por si só a fragilidade de se falar em uma situação de "isolamento social"16.

Outro aspecto que explicita a inadequação dessa concepção diz respeito ao efetivo conteúdo das relações sociais que se mantêm e daquelas que são restringidas nesse período de medidas mitigatórias da pandemia de covid-19. Como já destacaram outros autores, para boa parte das pessoas que podem permanecer em suas casas conforme as orientações sanitárias, seus lares só cumprem esse papel de "refúgio" em toda sua potencialidade por serem um nó pelo qual passam diferentes redes de recursos compostas por atores humanos e não-humanos (água, esgoto, mantimentos, medicamentos, energia, internet, etc. $)^{17}$. "Estar em casa", portanto, nos coloca em rede com os tantos outros espaços também vinculados ao oferecimento dos recursos utilizados nas casas.

Este sentido de integração também pode ser visto no fato de que o Estado é chamado a atuar em todos os cantos do mundo afetados pelo SARS-CoV-2 valendo-se de tecnologias de poder semelhantes sobre seus povos (LATOUR, 2020). Trata-se da já antiga atuação biopolítica do Estado na qual Michel Foucault veria concretizadas algumas de suas principais formulações. Um Estado que, ao performar sua gestão política da epidemia e de suas populações ${ }^{18}$, dirige suas ações ao controle do meio, "(...) um campo de intervenção em que, em vez de atingir os indivíduos como um conjunto de sujeitos de direito capazes de ações voluntárias - o que acontecia no caso da soberania -, em vez de atingi-los como uma multiplicidade de organismos, de corpos capazes de desempenhos, e de desempenhos requeridos como na disciplina, vai-se procurar atingir, precisamente, uma população." (FOUCAULT, 2008, p. 28) Nesse sentido, não são totalmente equivocadas aquelas reflexões que indicam este episódio sanitário global também como uma oportunidade que vem sendo aproveitada pelo Estado em diferentes partes do mundo 
e em distintos recortes administrativos para levar adiante medidas de exceção ${ }^{19}$ com características totalitárias ${ }^{20}$, necropolíticas e brutalistas $^{21}$. Essa constatação reforça a existência de linhas de conexão que articulam as ações de saúde pública de diferentes partes do mundo, impedindo-nos de compreendê-las como manifestações de "isolamento social".

Essa compreensão também é dificultada ao atentarmos para a intensificação de certos tipos de interação que ocorrem no atual momento. Em parte, propagada como solução final à finitude biológica humana (MBEMBE, 2020), o aprofundamento das interações virtualizadas viabilizado pela difusão do digital reforça sua posição de panaceia civilizacional e adiciona aspectos particulares a estes tempos. É certo que cumpre ainda investigar de forma mais detida as maneiras por meio das quais as reflexões sobre esse contexto podem ser estimuladas e complexificadas ao serem elaboradas a partir de ideias como as de unicidade técnica, alargamento dos contextos, convergência dos momentos, cognoscibilidade do planeta e aceleração contemporânea, processos caracterizantes do atual período técnico-científico-informacional (SANTOS, 1996; 2000). Apesar disso, vale reconhecer que o aparente paradoxo que a ideia de existir em "isolamento social" traz à experiência destes tempos tem levado à esperança de que interações fundamentais à nossa forma de ser possam ser mantidas por meio dos dispositivos técnicos digitais e das redes sociotécnicas e espaciais que eles permitem acessar, expectativa bastante regada pelo costumeiro grau de esquizofrenia que acompanha nossa convivência com a dualidade moderno-ocidental entre indivíduo e sociedade. Adensam-se as chamadas por vídeo, as mensagens de texto e áudio, o compartilhamento de informações — verdadeiras ou não - dos mais variados temas (saúde, política, relacionamentos, estudos, criação de jovens etc.), as palestras, debates e apresentações artísticas realizadas online. Torna-se mais incisiva a capilarização de suas funcionalidades em nossos cotidianos, explicitando-se em recomendações para uso de formas de ensino não-presencial, de consumo e de circulação de valores de formas digitais, de manifestações virtualizadas das diferentes fés, de exploração digital de lazeres e prazeres antes presenciais, dentre tantas outras faces, valendo-se inclusive de retórica sanitária. Estimula-se o aprofundamento, no limite, de formas de sociabilidade não apenas socio-ambientalmente degradantes, mas também mais aptas à implementação de instrumentos de vigilância e controle mais individualizado e eficaz no que diz respeito ao governo da população. Ao mesmo tempo, é este o ambiente em meio ao qual nos é prometido que serão encontrados os recursos para enfrentarmos a nova ameaça sanitária mundial. Apesar de quase metade da população do planeta ainda não acessar a rede mundial de computadores ${ }^{22}$, o conjunto de tecnologias de informação e comunicação que fazem parte do digital passaram a ser apontadas como ferramentas-chave para diferentes situações, dentre as quais destaco três: a coleta de dados epidemiológicos visando subsidiar estudos estatísticos sobre a pandemia e ações de saúde pública; a coleta de dados comportamentais das populações visando subsidiar as ações estatais de vigilância e controle populacional; e a análise de possibilidades de tratamento e imunização contra o SARS-CoV- $2^{23}$. No entanto, a ambiguidade dessas ferramentas pode ser constatada ao verificar-se que também por meio delas se desenvolvem formas associativas e comunitárias de atuação política frente a tal crise sanitária mundial e de críticas a governos nacionais, manifestando a versatilidade do tecido social e da plasticidade das formas de luta e ação política ${ }^{24}$.

Sendo assim, se a difusão global do patógeno causador da covid-19 ocorreu valendo-se de fluxos e conexões típicas da globalização; se são tão numerosos os fluxos de agentes humanos e não-humanos que precisam encontrar-se em nossas casas para que possamos restringir nossa circulação física pela cidades; se somos todas e todos objeto de 
tecnologias de poder implementadas nesse momento de maneiras semelhantes em diversas partes do mundo; e se são tantas as faces das interações virtualizadas que se aprofundam em nosso dia a dia nesses tempos pandêmico, então como afirmar que vivemos um momento de "isolamento social"?

Longe disso, o que há é uma readequação das interações sociais a partir das exigências ligadas a um caso extremo de saúde coletiva. Não é à toa que as questões que passam a dominar o pano de fundo do cenário atual - talvez infelizmente para quem cultiva um olhar esperançoso em relação aos tempos pós-pandêmicos — são aquelas voltadas à manutenção do cerne das interações sociais que estruturam nossa sociedade moderno-ocidental contemporânea: Como produzir? Como consumir? Como manter as relações de afeto? Essas recentes recomendações de redução da movimentação e de interação física também interferem em outras relações previamente existentes, reconfigurando-as ainda que momentaneamente. Isso pode ser visto ao atentarmos para os desdobramentos da intensificação das relações domésticas, por exemplo. Como falar em "isolamento social" se nestes tempos a interação doméstica — tão parte da sociedade quanto as aquisições na filial da rede varejista mais próxima, a rotina diária de busca pela renda familiar ou a presença em rituais religiosos - é inundada por relações muitas vezes socialmente secundarizadas, como aquelas estabelecidas com crianças ou mesmo aquelas já encharcadas pela violência doméstica de gênero e infantil ${ }^{25}$ ?

As dinâmicas do dia a dia são permeadas pelas influências dos diferentes espaços por onde circulamos ou em relação aos quais nos movemos. É assim com os veículos e circuitos de transporte urbano, os espaços de alimentação e de trabalho, os espaços educacionais e recreativos, os espaços de saúde e de cuidado. Nossos pequenos rituais diários, hábitos de comportamento, de consumo, de higiene e de expressão são todos nitidamente sensíveis às características materiais, políticas e simbólicas dos espaços nos quais estamos ou em referência aos quais agimos.

Em tempos pandêmicos e de recomendações de restrição de contatos físicos com outras pessoas em nome da contenção d' "A Curva" (transformada em substantivo próprio, dada sua sujeitificação), o recorte espacial da casa passa a ganhar maior destaque em nossas experiências cotidianas. Não é que ele não estivesse ali sempre, de maneira mais ou menos nítida em meio ao fluxo diário de atividades. É somente a percepção de que sua presença e características são vivenciadas de maneiras mais intensas e o fazem, portanto, ganhar em visibilidade no dia a dia. Apesar de ser obviamente polissêmica, a casa é evidenciada nas recomendações sanitárias. Ela está mais presente diariamente por nesse momento nos conter em seu interior e poder auxiliar na manutenção de agentes virais indesejados no seu exterior; mas ela também está presente em nosso cotidiano quando, sendo ou não potencialmente acessível, se apresenta como um espaço onde não se pode estar - como nos casos de pessoas convocadas ao trabalho, daquelas tantas sem condições de garantir a mínima subsistência caso não saiam à rua, ou mesmo das pessoas em situação de rua. A composição social de seus integrantes, as trajetórias individuais das pessoas que nela vivem, as características das relações que se desenrolam em seu interior, as condições de sua materialidade, sua localização em relação a serviços públicos de uso coletivo (incluindo transporte, saúde e educação), sua integração a redes de infraestrutura de saneamento e de fornecimento de energia e água, dentre outros, são aspectos espaciais cruciais para entendermos o significado dessa referência espacial. Todos eles, no entanto, são suscetíveis a adquirir novos sentidos em tempos de combate à difusão de um novo patógeno como o SARS-CoV-2.

Fato é que o interesse da Geografia com a casa não é exatamente novo, embora pouco tenha se destacado frente a outros temas tradicionais do campo. No Brasil, alguns poucos trabalhos têm esse enfoque, destacando sempre o papel que tiveram as geógrafas 
feministas ao darem nova vida ao assunto, estivessem elas inspiradas ou não em estudos pós-coloniais ${ }^{26}$. Desde a década de 1990 essas pesquisadoras desenvolvem críticas às formas como a casa, o lar e a família eram abordadas pela geografia marxista e humanista. Dentre elas estão Geraldine Pratt, Doreen Massey e Allison Blunt. Essa última, por exemplo, apontava o plano secundário ao qual a família, o lar e a casa eram relegadas pela geografia marxista, preocupada que estava com as relações de produção e os processos de trabalho (MOREIRA, 2013). Já a geografia humanista teria logrado diferenciar a casa do lar, mas sua compreensão sobre o lar enquanto "centro insubstituível de significância" 27 permanecia expressando apenas um olhar masculino sobre esse recorte e negligenciando as experiências de violência e opressão vividas neles por mulheres. A influência do pós-estruturalismo e do pós-colonialismo, por sua vez, ressaltou a compreensão da casa e do lar também enquanto espaços de crescimento e fortalecimento de mulheres negras, por exemplo. Tal debate, portanto, tem levado ao reconhecimento do lar como uma experiência e uma metáfora, além de um conceito ${ }^{28}$.

Essa pluralidade de experiências com a casa é um elemento constantemente presente em nosso cotidiano. Seu conteúdo político também é bastante ressaltado, sobretudo naquilo que envolve o uso desses espaços para o controle dos comportamentos das classes populares à luz dos desejos das classes dominantes. Como sumaria Moreira (2013), inspirada nas reflexões do historiador e sociólogo urbano francês Jacques Donzelot, as intervenções estatais sobre a habitação popular, por exemplo, buscaram restringir as formas de habitar a partir dos desejos da burguesia ao organizarem espaços que zelassem por três aspectos: serem amplos o suficiente para serem considerados higiênicos; pequenos o bastante para que só uma família pudesse neles viver; e com uma organização interna que permitisse que os pais vigiassem seus filhos. A ideia de "higiene", por sinal, pode ser entendida enquanto um dispositivo construído socio historicamente e frequentemente utilizado também para o controle das populações pobres, sobretudo em momentos propícios ao aprofundamento de medidas de exceção que incidem sobre os espaços domésticos e intensificam o controle sobre as populações

Um dos pressupostos presentes sob a ideia de nossos tempos pandêmicos de que restringir-se ao espaço doméstico trata-se de "isolamento social" é o de que a casa seria um espaço capaz de ser totalmente diferenciado do restante da sociedade. Falar em "isolamento social", portanto, assume a existência de uma fronteira nítida entre a casa e a sociedade. Tal concepção, no entanto, fere a realidade, sobretudo quando reconhecemos as múltiplas formas por meio das quais a casa se mostra parte integrante da sociedade e, concomitantemente, a sociedade apresenta-se cruamente como constituidora do espaço doméstico. Se consideramos que os agentes sociais, por meio dos conflitos ao redor das ações protagonizadas por eles e pelos processos sociais que se desenrolam a partir dessas interações, não só perpassam os recortes espaciais herdados do passado mas também os constroem no decorrer dessas trajetórias espaço-temporais, somos levados a afirmar que as relações sociais que produzem cada uma das escalas geográficas do mundo inserem nelas um fio condutor que as unifica. Por isso, enquanto uns diriam que "ser bairro é ser cidade" (BAHIANA,1986), é possível dizer também que ser casa é ser sociedade. Ao mesmo tempo, nada impede que se afirme também que a sociedade como um todo também muitas vezes é interpretada por meio de ideias vinculadas a dinâmicas concebidas como domésticas, sendo vislumbrada enquanto morada, espaço de conflitos, de disputas e de embates que a constroem cotidianamente ${ }^{29}$. O período pelo qual passamos, notadamente sob a influência das recomendações sanitárias ligadas ao controle da pandemia de covid-19, coloca muitas pessoas em situação de contato intenso com uma constatação já óbvia a grandes parcelas da sociedade: que enquanto uma das escalas espaciais da experiência cotidiana, a casa acolhe de maneira exemplar o colapso das 
escalas geográficas que constituem a realidade. Mesmo assim, resta saber em que medida o momento que enfrentamos reposiciona a casa em relação a outras escalas geográficas no arranjo escalar dominante da sociedade moderno-ocidental contemporânea - ainda que talvez o faça apenas de forma temporária.

Sobressai-se, nestes tempos, portanto, a importância dada à escala espaçotemporal do cotidiano. Sempre em constituição e mudança, é em função dela que somos instigados a conhecer outros espaços. Esse recorte espaço-temporal é que, por meio da experiência, nos leva a buscar aspectos de outros espaços e momentos que influenciem, expliquem e, assim, deem sentido ao seu desenrolar. Ao construir esse sentido em função de sua relação com os sentidos conferidos a outros espaços e momentos, também construímos compreensões sobre aqueles outros espaços e momentos. São forjadas, assim, compreensões do mundo e do lugar de nossa experiência vivida nele. A partir da escala espaço-temporal do cotidiano constrói-se o sentido escalar da experiência.

\section{Medidas sanitárias, o déficit habitacional e o complexo de comorbidades}

Em meio ao continuum de nosso cotidiano pandêmico, a casa tem sido um recorte espacial que tem ganho destaque. É difícil esquecer, no entanto, das características urbanas desta pandemia, já lembradas por alguns autores ${ }^{30}$. Afinal, tanto o epicentro originário quanto os principais nós mundiais da difusão do SARS-CoV-2 compartilham aspectos como a grande (e crescente) densidade populacional e a centralidade dos posicionamentos dessas aglomerações em relação às redes urbanas globais e nacionais. $\mathrm{O}$ adensamento e intensa conectividade desses centros facilitam a difusão de patógenos como o novo coronavírus, contribuindo para a caracterização dessa emergência sanitária global como fortemente ligada às dinâmicas dos espaços urbanos contemporâneos sobretudo em sua forma metropolitana. Isso ocorre apesar do processo de difusão espacial da epidemia apontar sua incontornável interiorização, valendo-se especialmente das vias de comunicação física que - em conjunto com outros canais de circulação de fluxos nãomateriais - constituem as redes urbanas nacionais e estabelecendo-se como importante eixo espacial estruturador da capilarização do vírus tanto pelas cidades médias e pequenas quanto pelos espaços rurais ${ }^{31}$.

Sendo assim, o destaque da casa enquanto recorte espacial de relevo nesse momento se refere em grande parte à casa localizada em meio ao tecido urbano. No entanto, como lembrado há pouco e em diversas reflexões acadêmicas e jornalísticas, são explícitas as disparidades que compõem as experiências em relação à pandemia, tal qual o são em relação aos espaços urbanos e aos recortes domésticos. Obviamente não é novidade a visibilidade que as desigualdades sociais ganham em tempos de emergência sanitária. Como também já foi mencionado, esses eventos não só se desenrolam sobre características socioespaciais herdadas dos tempos pré-pandêmicos, no caso, como também tornam-se oportunidades para que agentes sociais dominantes reforcem seu controle sobre parcelas populacionais subalternizadas, aprofundando tais disparidades. Enquanto instrumentos de exercício de poder, as imposições sanitárias colocadas sobre a população tratam de diferenciar, na prática, aquelas pessoas que poderão cumpri-las e aquelas que não terão condições para tal - no nosso caso, seja por serem convocadas a trabalhar, seja pela necessidade de sair de casa para conseguirem recursos para sobreviver. Dentre essas, é difícil não perceber a predominância dos corpos que, transformados em margem sobre a qual o Estado segue seu avanço ${ }^{32}$, são histórica e geograficamente construídos ao longo de trajetórias de exposição aos mais perversos riscos sociais, ambientais e biológicos (MBEMBE, 2020). 
Se os espaços domésticos ganham especial relevância nos tempos atuais e o contexto desses recortes é majoritariamente urbano até agora, certamente alguns debates caros aos estudos urbanos e, em decorrência, à geografia urbana trazem contribuições singulares para a complexificação das reflexões sobre esse momento. Considerações relevantes podem ser sem dúvida elaboradas a partir de estudos específicos interessados em diferentes temas, seja a partir do olhar sobre a rede urbana ou sobre o espaço intraurbano ${ }^{33}$.

A distribuição espacial dos casos de contaminação por covid-19 nos diferentes bairros, por exemplo, pode levantar questões instigantes sobre as dinâmicas ligadas às centralidades urbanas e à circulação de pessoas. Esta mobilidade, em tempos pandêmicos, envolve, por um lado, aqueles sujeitos que compõem a força de trabalho de atividades consideradas essenciais à manutenção da alimentação, limpeza, saúde ou segurança. Tal conjunto de sujeitos, no entanto, tampouco podem ser observados de maneira generalizante. Há diferenças significativas que distinguem a faxineira empregada nas residências das classes abastadas, o entregador que oferece seus serviços em aplicativos, as caixas sub-remuneradas de mercados ou os maqueiros das emergências hospitalares, por exemplo, de médicas e médicos anestesistas de hospitais privados ou do alto escalão concursado responsável pela gestão de hospitais públicos. São distinções ligadas aos riscos que correm, às condições materiais das quais usufruem, ao acesso que têm a informações e recursos materiais, ao status social que detêm, à remuneração que recebem e a tantas outras linhas de diferenciação social. Por outro lado, porém, estudos sobre a circulação urbana em tempos de SARS-CoV-2 também devem englobar aqueles indivíduos obrigados a circular em decorrência da precariedade de suas condições de emprego e renda, por exemplo, dependentes de atividades muitas vezes desenvolvidas no contexto do circuito inferior da economia urbana (SANTOS, 2008). Outros tantos estudos relacionados à mobilidade urbana em nosso atual contexto podem abordar a espacialidade envolvida na circulação motivada pelas mais variadas razões que costumeiramente já mobilizavam os indivíduos em seus périplos urbanos, seja desde um ponto de vista comparativo aos trânsitos realizados antes da pandemia ou não. Outro tema que certamente estimularia investigações perspicazes seria a distribuição da oferta de serviços de uso coletivo pela cidade neste período que vivemos, indo das condições dos sistemas público e privado de atendimento de saúde às condições diferenciadas da infraestrutura espalhada ao longo do tecido urbano que resultam, por exemplo, na restrição de acesso a condições mínimas de saneamento básico e fornecimento de água à população residente em determinadas áreas da cidade. As pesquisas filiadas à trajetória de estudos sobre a estrutura urbana das cidades brasileiras, por outro lado, podem enfocar aspectos centrais para a compreensão das experiências vividas neste contexto sanitário, como a influência dos padrões de segregação sobre o cotidiano dos habitantes das cidades.

Levantar esta última possibilidade de investimento intelectual nos leva à necessidade de enfatizar a diversidade dos espaços habitacionais que se materializam nas diferentes cidades. No contexto brasileiro um elemento definidor tanto da diversidade habitacional quando da segregação estruturante do espaço urbano é a conhecida precariedade de grande parte dos espaços habitacionais populares. No limite, tal precariedade se manifesta por meio da situação de déficit habitacional vivida no país.

Em números concretos, os dados mais recentes sobre esse tema dizem respeito ao ano de 2015 referentes às informações coletadas pelo Instituto Brasileiro de Geografia e Estatística (IBGE) por meio da Pesquisa Nacional por Amostra de Domicílios (PNAD) de 2015. Em relação à temática habitacional, os estudos da Fundação João Pinheiro fazem parte das principais referências no país, tendo sua equipe se debruçado sobre os dados de 2015 para elaborar seu relatório mais recente sobre o tema (FJP, 2018). A metodologia de 
tratamento dos dados construída pela FJP no decorrer de seus estudos sobre o tema, que datam inicialmente do ano de 1995, envolve a análise de dois tipos de necessidades habitacionais: o déficit habitacional, que mensura a quantidade absoluta de novas unidades habitacionais necessárias para atender a demanda da população em um dado momento; e a inadequação de moradias, que quantifica as moradias que apresentam especificidades internas que prejudicam a qualidade de vida de suas moradoras $\mathrm{e}$ moradores ${ }^{34}$. Em quantidades totais, o relatório da FJP indica os seguintes quadros relativos ao déficit habitacional brasileiro em 2015 (Tabela 1) e às situações de inadequação domiciliar (Tabela 2), ambos apresentados a seguir distinguindo seus totais e os valores relativos aos seus componentes e com destaque à situação da Região Metropolitana do Rio de Janeiro.

\begin{tabular}{c|r|r|r|r|r}
\hline \multicolumn{7}{c}{$\begin{array}{c}\text { Tabela 1: } \\
\text { Déficit Habitacional - Brasil 2015 } \\
\text { (Total e Componentes) }\end{array}$} \\
\hline & Habitação precária & $\begin{array}{c}\text { Coabitação } \\
\text { familiar }\end{array}$ & $\begin{array}{c}\text { Ônus excessivo } \\
\text { com aluguel }\end{array}$ & $\begin{array}{c}\text { Adensamento } \\
\text { excessivo }\end{array}$ & \multicolumn{1}{c}{ TOTAL } \\
\hline Brasil & 942.631 & 1.902 .490 & 3.177 .772 & 332.850 & 6.355 .743 \\
\hline Percentual do total & $14,8 \%$ & $29,9 \%$ & $50,0 \%$ & $5,2 \%$ & $99,9 \%$ \\
\hline RM Rio de Janeiro & 9.531 & 75.156 & 224.906 & 28.529 & 338.122 \\
\hline Percentual do total & $2,8 \%$ & $22,2 \%$ & $66,5 \%$ & $8,4 \%$ & $99,9 \%$ \\
\hline
\end{tabular}

\begin{tabular}{l|r|r|r|r|r}
\hline \multicolumn{7}{c}{ Inadequação de Domicílios - Brasil 2015 } \\
(Total e Componentes)
\end{tabular}

Para o cálculo do déficit habitacional, são levados em conta quatro componentes: habitação precária, coabitação familiar, ônus excessivo com aluguel urbano e adensamento excessivo de moradores em domicílios alugados. Ao atentarmos às definições de cada um deles à luz de nosso atual contexto de recomendações sanitárias feitas pela OMS (com base nas evidências científicas disponíveis até o momento) é possível destacar algumas condições habitacionais que oferecem obstáculos à prevenção adequada contra o contágio por SARS-CoV-2. A habitação precária, primeiro componente do déficit habitacional, contabiliza tanto os considerados domicílios rústicos quanto aqueles denominados domicílios improvisados. Dentre esses últimos são considerados “(...) todos os locais e imóveis sem fins residenciais e lugares que servem como moradia alternativa (imóveis comerciais, embaixo de pontes e viadutos, carcaças de carros abandonados, barcos, cavernas, entre outros) (...)." (FJP, 2018, p. 21) Considerando que a maioria desses locais de moradia indicam a forte tendência de apresentarem condições precárias de acesso à água, saneamento e ventilação, bem como a impossibilidade de isolamento de membros da família eventualmente infectados pelo SARS-CoV-2, podemos ver nessa condição habitacional também uma situação de risco ampliado para a disseminação da enfermidade provocada por esse patógeno. A coabitação familiar, segundo componente, considera situações em meio às quais são incluídas tanto as famílias que convivem no mesmo domicílio que outra família considerada principal, quanto aquelas de famílias que viviam em casas de cômodo e cortiços. Nesses últimos casos, a condição indica também uma possível dificuldade de isolamento de integrantes da família 
que eventualmente estejam com covid-19 no mesmo domicílio, facilitando novos contágios pelo vírus que causa a doença. O terceiro componente do déficit habitacional, o ônus excessivo com aluguel urbano, indica os casos nos quais uma família com renda de até três salários mínimos gasta mais de $30 \%$ de sua renda com o pagamento de aluguel — o que seria o equivalente hoje ao gasto de cerca de $\mathrm{R} \$ 940$. Tal situação indica prováveis restrições do percentual da renda familiar mensal destinada à alimentação e produtos de limpeza, fator que impacta as condições de manutenção de um regime alimentar compatível com um sistema imunológico robusto e de higienização eficiente contra o SARS-CoV-2. Assim, tais casos também apontam para condições desfavoráveis à completa adoção das medidas sanitárias sugeridas pelos órgãos internacionais. Por fim, o quarto e último componente do déficit habitacional contabilizado pela FJP, o adensamento excessivo de moradores em domicílios alugados, leva em conta aquelas situações nas quais há um número médio de moradores superior a três pessoas por dormitório no domicílio. Em uma situação como essa também tendem a ser restritas as possibilidades de isolamento de indivíduos potencialmente contaminados com o novo coronavírus, aumentando o risco de transmissão da doença para as demais pessoas do domicílio e destas para outros de seus contatos - sobretudo caso a medida de quarentena não possa ser adotada.

Para a contabilização da inadequação de domicílios, a Fundação João Pinheiro considerados cinco componentes: carência de infraestrutura urbana, adensamento excessivo de domicílios urbanos próprios, ausência de unidade sanitária domiciliar exclusiva, cobertura inadequada e inadequação fundiária urbana. Eles descrevem aspectos das habitações que não são mutuamente exclusivos e cujas características também podem ser facilmente contrastadas com as recomendações gerais estabelecidas pela OMS para redução dos riscos de contágio pelo SARS-CoV-2. O primeiro componente que caracteriza os domicílios considerados inadequados é a carência de infraestrutura urbana, situação na qual o domicílio não dispõe de ao menos um dos seguintes serviços básicos: energia elétrica, abastecimento de água, esgotamento sanitário e coleta de lixo. Sobretudo nos casos de falta de acesso a abastecimento de água e a esgotamento sanitário, nota-se a precariedade das condições materiais necessárias à manutenção de hábitos de higiene indicados como eficientes na diminuição do risco de contágio pelo novo coronavírus, o que facilita sua difusão. O segundo componente, o adensamento excessivo de domicílios urbanos próprios, utiliza como referência situações habitacionais nas quais há mais de três moradores por dormitório no domicílio, tal qual o adensamento excessivo de imóveis alugados contabilizado no déficit habitacional. Como afirmado antes, portanto, essa situação também impacta a capacidade de isolamento de pessoas que tenham potencialmente contraído covid-19, potencializando o surgimento de novos contágios dentro do domicílio ou fora (no caso da quarentena não poder ser seguida). A ausência de unidade sanitária domiciliar exclusiva, terceiro componente, considera situações nas quais o domicílio não possui um banheiro exclusivo, condição que, como a anterior, também dificulta o isolamento domiciliar em caso de contágio por SARS-CoV-2 - além de limitar a adoção de medidas de distanciamento social, uma vez que as/os moradoras/es de um domicílio se vêm obrigadas/os a compartilhar unidades sanitárias com pessoas de outro domicílio. A falta de cobertura considerada adequada, quarto componente da inadequação familiar considerado pela FJP, inclui em sua contabilização as habitações com telhados de madeira aproveitada, zinco, lata ou palha, condições com baixo impacto sobre as medidas de prevenção contra a covid-19. Por fim, o quinto e último componente considerado aqui é a Inadequação fundiária urbana, situação na qual algum morador possui a propriedade da moradia, mas não do terreno ou da fração ideal correspondente na qual se localiza (total ou parcialmente). Embora muitas 
das moradias encontradas nas favelas e loteamentos irregulares das metrópoles brasileiras, por exemplo, encontrem-se em tal situação, são geralmente os desdobramentos da situação de irregularidade fundiária no que se refere ao acesso a serviços básicos essenciais que mais afetam as condições de prevenção contra o novo coronavírus - e não a irregularidade fundiária em si.

O contraste exercitado entre os componentes que compõe os dados concretos (embora defasados e subdimensionados) das situações de déficit habitacional e de inadequação de domicílios no país e as recomendações sanitárias da OMS no que se refere às medidas de contenção da difusão do SARS-CoV-2 e de tratamento dos casos de contágio por covid-19 (especialmente aquela ligada ao isolamento domiciliar dos indivíduos infectados) deixa entrever, portanto, a perversidade da sobreposição entre o impacto desta pandemia e os espaços habitacionais já previamente fragilizados. Se todos os componentes do déficit habitacional, por um lado, indicam condições que dificultam a adoção das medidas sanitárias recomendadas, podemos concluir que seu número total indica também o número total de núcleos domiciliares que possivelmente enfrentam limitações em seus cuidados frente à atual pandemia — ou seja: mais de 6,3 milhões de domicílios (mais de 330 mil somente na RMRJ). Ao mesmo tempo, se considerarmos os dados mais recentes da PNAD Contínua referentes ao tamanho médio das famílias brasileiras em 2018 (IBGE, 2020), vemos que cada domicílio no Brasil conta em média com 2,9 pessoas (2,7 na RMRJ). Disso concluímos que a situação de déficit habitacional brasileiro, prévia à epidemia global de covid-19, força mais de 18,4 milhões de pessoas no país (mais de 910 mil na RMRJ) a conviverem com situações de maior risco de contágio e de tornarem-se vetores de difusão do SARS-CoV-2 junto às pessoas com as quais convivem nos mais diferentes espaços. Podemos também exercitar essa análise para os dados referentes à inadequação domiciliar, embora eles não possam ser somados pelo risco de dupla contagem de domicílios. Ainda assim, considerando apenas os componentes que indicam situações que influenciam diretamente as condições plenas de adoção das medidas sanitárias sugeridas pela OMS e o mesmo tamanho médio das famílias recém-indicado, teríamos que: os mais de 1,6 mil domicílios sem banheiro impactam mais de 4,5 mil pessoas em suas condições de proteção contra a covid-19; os mais de 150 mil domicílios com adensamento excessivo impactam mais de 410 mil pessoas; e os mais de 210 mil domicílios com carência de infraestrutura condicionam mais de 570 mil pessoas a conviverem com o risco ampliado de serem infectadas e tornarem-se retransmissoras do novo coronavírus.

Essa dimensão ressalta como os aspectos da materialidade herdada do espaço interferem diretamente sobre as condições de prevenção e cuidado de parcelas específicas da população. São óbvias as consequências sobre o conjunto da saúde pública e da população desses fatores de ampliação dos riscos de contágio e difusão. Como desdobramento dessa análise rápida e dos outros tantos fatores já vêm sendo destacados por outras autoras e autores, é coerente incluirmos como comorbidades que acentuam o risco de determinadas populações frente à covid-19 os fatores socioeconômicos e espaciais. Estes definem as comorbidades histórico-espaciais às quais tais grupos estão expostos. Já se encontram relatos de pesquisas que apontam, afinal, as diferentes formas como esta pandemia tem impactado mulheres, negras/os, populações em situação habitacional precária ou altamente adensadas, povos indígenas e de comunidades tradicionais, dentre outros ${ }^{35}$. Estas populações são compostas pelos "corpos vivos expostos à exaustão" (MBEMBE, 2020), aqueles já maltratados pelos malefícios das disparidades socioespaciais construídas histórica e socialmente no decorrer dos últimos séculos. São corpos que já apresentavam, antes destes tempos de covid-19 e por conta dessas construções sócio-históricas, enfermidades que debilitam gravemente sua saúde, a 
de suas gerações futuras e mesmo a de suas/seus mais velhas/os, quando ainda vivos. Hoje, essas enfermidades são apontadas como as comorbidades médicas que ampliam os riscos de desdobramentos fatais da infecção pelo SARS-CoV-2. Mas elas são, na verdade, resultantes de processos históricos. Portanto, a rigor tais populações experienciam seus cotidianos pandêmicos convivendo com as angústias de carregarem em seus corpos um intrincado e brutal complexo de comorbidades médico-sociais.

\section{Considerações finais: entre limites presentes e lutas futuras}

No debate sobre as escalas geográficas um dos consensos contemporâneos gira ao redor das dificuldades de estabelecermos de forma nítida os aspectos que determinam os limites existentes entre os diferentes recortes do espaço que, quando organizados em configurações com sentido de totalidade, constituem os arranjos escalares que guiam nossas compreensões sobre os processos socioespaciais. Definir os aspectos que tornam um recorte espacial diferente de outro e que, com isso, também estabelecem relações entre esses recortes de maneira a organizar a realidade ao redor (ou no interior) de alguma ideia de totalidade envolve processos nada simples. Trata-se de um problema de demarcação espacial que explicita um dos desdobramentos da complexificação que os estudos sensíveis à dimensão identitária das relações sociais trouxeram à academia no decorrer do último século — ainda que essas preocupações já tivessem estado presentes no pensamento geográfico em outros momentos de sua trajetória enquanto campo científico. Embebidas desse reconhecimento, muitas reflexões interessadas pela escalaridade das relações sociais têm reforçado o caráter político-epistemológico da definição desses recortes, de suas margens e das relações que estabelecem entre si (incluindo sua organização em totalidades). Tal complexidade originou um léxico específico que foi incorporado em diferentes estudos em nosso ambiente acadêmico - como o caso do termo glocal e seus derivados (como glocalização) (SWYNGEDOUW,1997), política de escalas (SMITH,1992 e 1993; SWYNGEDOUW, 1993; HEROD e WRIGHT, 2002) e fixos escalares (SMITH, 1993 e 2004) - e que explicita o fato de que, a rigor, as interpretações sobre os processos que constituem concreta e simbolicamente nossas realidades já não podem mais ser guiadas por leituras que primam por buscar as escalas espaciais que os determinam. Afinal, tais abordagens não só reificam esses constructos político-epistemológicos - e o próprio espaço, já que assumem as escalas como agentes - como também simplificam a compreensão dos processos sociais, históricos e espaciais que produzem nossas realidades. A escalarização das interpretações sobre o mundo, procedimento epistemológico caro a diversos campos da academia, é um artifício intelectual importante para que se destaque processos que, a rigor, nunca se restringem a recortes espaciais específicos. Não é possível, portanto, assumir que o continuum da realização concreta e simbólica do mundo ocorre a partir de recortes espaciais prédefinidos.

Neste momento de pandemia, o exercício de raciocínio escalar proposto nestas páginas tomou como referência inicial o processo que vem sendo popularmente chamado de "isolamento social". Este processo instaura explicitamente um limite, uma fronteira e suas margens. Essa linha, tanto imaginária quanto material, demarca e cria um recorte espacial que, valorado em relação aos demais, conforma uma escala geográfica: a casa. Ela ganha destaque cotidiano por ser o nome dado ao recorte espacial mais comum onde esse processo pode se realizar. Ainda assim, vale lembrar que trata-se de um recorte que, mesmo fora de períodos de medidas sanitárias restritivas às interações sociais marcadas pela copresença física dos sujeitos, tem grande centralidade para parcelas numericamente relevantes da população que, no entanto, também são as que constituem as parcelas 
politicamente subalternizadas em nossa moderno-colonialidade patriarcal - como é o caso de boa parte das mulheres e de trabalhadoras e trabalhadores domésticos em nosso mundo.

O foco nesse processo permite ressaltar que a casa também pode ser vista, nesse e em outros momentos, como o epicentro de um colapso escalar: para esse recorte convergem processos e fluxos - de indivíduos, de bens, de energia, de afetos, de violências, de desigualdades, de opressões, etc. — originados em outros recortes espaciais e que são vividos na intensidade de seus desdobramentos diários. A complexidade de sentidos que tal escala possui é sublinhada em um momento como o atual, no qual as recomendações sanitárias levam muitos dos sujeitos tradicionalmente em posições de privilégio a conviverem excepcionalmente com as dinâmicas domésticas.

Como espaço, a casa expressa as desigualdades estruturantes de nossa sociedade, por exemplo, por meio de sua estrutura material-concreta, de seu adensamento, de sua localização no interior da estrutura e do tecido urbano, das características dos sujeitos que a habitam e das relações que estabelecem entre si. As disparidades também ficam explícitas quando o sentido da casa flutua entre ser refúgio, abrigo ${ }^{36}$, risco (de contágio de entes queridos, por exemplo) ou masmorra (onde reincidem os casos de violência doméstica de gênero e infantil). Ao mesmo tempo, a casa torna-se referência espacial de posicionamentos políticos em um contexto da politização do cotidiano desde uma abordagem polarizadora como o que vivemos, desdobramento em parte da difusão do ódio e do medo como ferramentas de mobilização das paixões e controle das condutas das populações em diferentes locais do globo (Brasil e Rio de Janeiro inclusos). Adotar ou não as medidas sanitárias recomendadas de restrição de circulação e contato físico com outras pessoas, por exemplo, adquire sentidos de filiação ou não a leituras de mundo ou preferências político-partidárias específicas.

Trata-se de retomar o debate sobre a ideia de limite, tão importante para as reflexões humanas, em uma das faces de sua expressão espacial. Em termos escalares, o colapso escalar que ocorre sobre a casa - mas também sobre o hospital, sobre o vagão do trem e sobre o ônibus do transporte público, sobre a rua da favela e sobre a marquise do edifício de escritório do centro da cidade, sobre o banco da caixa do supermercado e sobre as rodas dos entregadores de delivery - demonstra a contiguidade espacial da experiência e o desafio de se considerar a segmentação dos processos sociais como algo que vá além de uma representação parcial do vivido. É importante ressaltar: não se trata de desprezar o recorte de processos e espaços como procedimento epistemológico extremamente útil à análise social. Os limites e suas margens são realidades materiais e simbólicas que constituem e mediam as relações humanas. O intuito é, no entanto, destacar que o sentido construído para dinâmicas ocorridas em outros espaços (aconteçam elas de forma concomitantes ou não) depende em grande parte da mediação realizada no contato dessas dinâmicas com o experienciado.

Muitos aspectos estruturam, porém, as desigualdades que condicionam as diferentes experiências cotidianas, inclusive neste momento de pandemia e em relação ao espaço da casa. Como apontado em diferentes momentos deste texto, o caráter polissêmico das experiências com a casa é bastante evidente. Por isso, muitas autoras e autores da academia e de diferentes veículos de comunicação afirmaram que vivenciar tal momento enquanto mera contenção da liberdade é muitas vezes parte da manifestação de alguns dos privilégios que constituem nossa sociedade. Trabalhadoras/es que podem manter-se ativas/os em suas funções produtoras de valor economicamente remuneradas desde suas residências ou aquelas pessoas que desfrutam mais rotineiramente da mobilidade intra e inter urbana. Para outras pessoas, no entanto, a restrição de movimentação é uma contenção a um espaço com recursos restritos para o desenrolar de 
dinâmicas cotidianas e o estabelecimento de rotinas consideradas importantes tanto diante das atuais recomendações sanitárias em período de covid-19 quanto para a manutenção de um sistema imunológico resistente às possíveis complicações médicas que possam decorrer da infecção pelo SARS-CoV-2. Afinal, são poucas as pessoas que têm em suas casas espaço para manter atividades físicas motivadoras, para desenvolver atividades lúdico-pedagógicas instigantes com suas crias ou para desfrutar dos prazeres da individualidade na privacidade do lar, por exemplo. Há ainda quem não tenha condições de sequer permanecer em suas casas e restringir, assim, os riscos de contaminação própria e de seus próximos. Nesse grupo inserem-se tanto aquelas pessoas consideradas "trabalhadoras de atividades essenciais" quanto aquelas situadas em algumas das posições mais precarizadas em termos trabalhistas das cidades contemporâneas, especialmente em países semiperiféricos como o nosso (entregadores, ambulantes, trabalhadores de aplicativos etc.). Parte do desconforto generalizado que a atual situação de "isolamento social" traz às nossas sociedades envolve inclusive o fato de que o novo coronavírus valeu-se das rotas de circulação das elites socioeconômicas mundiais para difundir-se, levando à necessidade — certamente momentânea — de restrição da mobilidade desses agentes. Tal "contenção às avessas" (HAESBAERT, 2020b) na qual são os privilegiados que precisam inicialmente se autoconter em suas casas para não espalhar o vírus, porém, não rompe um aspecto central da estrutura social desigual que organiza nossa sociedade, pois seu controle sobre a mobilidade - sua e do Outro — permanece intocado. São seus integrantes que podem condicionar o seu movimento no sentido de autopreservação e, ao mesmo tempo, impor a movimentação (e o maior risco) aos sujeitos dos setores populares - que, não raro, movem-se em nome da manutenção da acumulação de capital desfrutada por parte da mesma elite hoje entrincheirada em suas casas-bunker e responsável pela circulação global da covid-19. Nesse momento, mais uma vez, o privilégio é expressado pela possibilidade de agir sobre a ação do Outro (FOUCAULT, 1995), de controlar sua movimentação no espaço: quem tem maior controle pode, assim, proteger-se e expor-se menos ao permanecer em casa; a quem não cabe essa fortuna, restam os riscos de mobilizar-se mandatoriamente pelas cidades em nome das dinâmicas laborais e/ou do imperativo da garantia mínima de sua reprodução social. As relações de dominação e subalternização prévias à pandemia, assim, se reproduzem e reforçam, controlando a população, seus corpos e seus territórios.

Se concordarmos que o marco zero da existência e da experiência é o corpo (HAESBAERT, 2020b; LIMA, 2020; BARBOSA, 2020), faz sentido então reconhecermos o peso que seu controle social tem na vivência da espacialidade e da geopolítica da atual pandemia. Diante das recomendações de "isolamento social", tal controle se vale de uma espacialidade na qual o recorte da casa ganha relevo. Ocorre que, por assumirmos a inexistência de um sujeito universal e, portanto, a necessidade de situálos, as desigualdades espaciais e interseccionais que constroem, atravessam e compõem os corpos, suas formas de existir e de experienciar o mundo - incluindo o recorte espacial da casa, onde ele também se concretiza - gritam aos ouvidos. Como mencionado páginas atrás, além de grupos de risco, há populações inteiras mais vulneráveis à pandemia, compostas pelos corpos com condições de proteção prévia fragilizadas ou inexistentes e que, em caso de complicações graves derivadas de um eventual contágio, somente contam com um parco atendimento de saúde insuficiente e precarizado por décadas de políticas econômicas e sociais neoliberalizantes.

É impossível não saltar aos olhos, diante disso, um dilema frequentemente presente nos textos até agora difundidos sobre o contexto de pandemia. Este seria ou não um momento de guinada civilizatória? A pandemia, assim, antecederia a atual versão do apocalipse ou seria a oportunidade de gestar o alvorecer de uma nova sociedade? 
Esse questionamento soa comum diante de eventos críticos, sobre o que talvez a psicologia, sociologia ou antropologia teriam mais coisas a dizer. O último século teve diversos momentos que, em graus diferentes, foram requisitados por muitas pessoas como verdadeiros turning points civilizatórios: revoluções, guerras mundiais, pandemias, epidemias, crises alimentares, eventos climáticos, quebras financeiras generalizadas, etc. Em meio a sujeitos desejosos por mudanças sociais, sobretudo aqueles mais apegados às tradições da esquerda moderno-ocidental — como boa parte das pessoas que se perguntam sobre essas questões - é recorrente se perguntar se cada evento crítico pelo qual passamos não será, finalmente, a tão sonhada "gota d'água" depois da qual todas e todos perceberão a "real" necessidade de mudança. Ninguém que fosse iluminado por fatos tão cristalinos como tais momentos críticos optaria, em sã consciência, pela barbárie em detrimento de uma mudança social profunda. Essa percepção, afinal, ecoaria o que desejamos, atuando como reforço positivo ao nosso ego: "estávamos certos desde o início!", diríamos.

Fato é que haveria muito o que se pensar sobre essa tendência a esperarmos por um momento especial para que as mudanças ocorram, como se os processos sociais estivessem dependendo de episódios espetaculares para sofrer mudanças significativas. Obviamente não se pode negar que tais processos histórico-espaciais sejam constituídos por sequências de eventos. Tampouco se pode desmerecer a influência que tais eventos têm na construção dos rumos dos processos sociais, sejam eles tomados em seu conjunto ou individualmente. Embora torça para que alguma virada civilizacional nesse sentido chegue antes de nossa extinção da Terra enquanto espécie e, ao mesmo tempo, entenda o sentido profundamente político e necessário da esperança, talvez caiba nos perguntarmos se havia algo no mundo pré-pandêmico que apontava para possibilidades efetivas de alteração dos rumos civilizatórios que vínhamos traçando ou se, pelo contrário, vivíamos às voltas com processos de aprofundamento e intensificação daquilo que combatemos.

Em que diferem fundamentalmente, por exemplo, as manifestações de solidariedade e ações coletivas que vemos atualmente no contexto da pandemia de covid19 daquelas há tanto tempo presentes no cotidiano das classes populares, dos povos ameríndios e de outras tantas populações subalternizadas? Como já apontado em diferentes campos das ciências sociais e humanas, não teriam sido essas práticas que, em certa medida, garantiram a muitas dessas populações sua sobrevivência diante de investidas genocidas de seus opositores civilizatórios? Ao mesmo tempo, essas populações periféricas vulnerabilizadas também têm convivido diariamente com agentes políticos promotores de outros valores que, na última década pelo menos, conquistaram amplitude suficiente para forçar o pêndulo político-ideológico mundial para a direita.

Embora seja difícil questionar atualmente o impacto que o SARS-CoV-2 tem sobre a capacidade de tratamento do sistema de saúde brasileiro - sobretudo ao levarmos em conta os dados a respeito da crescente ocupação dos leitos destinados a tratamentos intensivos e seus desdobramentos no que envolve a possibilidade de acolhimento médico não de só novas pessoas infectadas pela covid-19 mas também aquelas acometidas por outros casos graves de saúde - não se pode desconsiderar o alerta levantado por alguns analistas a respeito de como os diferentes Estados e frações das classes dominantes têm se valido desta emergência sanitária global para experimentar mecanismos de implementação de controle minucioso dos corpos do nível individual ao nacional (ZIBECHI, 2020a; AGAMBEN, 2020) e de reforço da autoridade do Estado (LATOUR, $2020)^{37}$ sobre a população.

Os ativismos e movimentos sociais, por sua vez, não são novidades nos cenários periféricos brasileiros, ainda que tenham nas últimas décadas passado por diversas mudanças que envolveram suas pautas, sua composição social, o perfil das populações 
junto às quais atua, suas práticas socioespaciais, seus resultados concretos, suas alianças, suas simbologias, suas formas de ação, dentre tantos outros aspectos. São eles que, em momentos críticos, muitas vezes forneceram as condições materiais e afetivas básicas para que essas populações enfrentassem situações de violência estatal, desabamentos, incêndios, enchentes, desamparo médico e violência patronal, por exemplo. Desses períodos podem ou não emergir vínculos que potencializem a capitalização da disputa cotidiana pelas formas materiais e simbólicas de existência que tais agentes sociais protagonizam.

Do que temos certeza, porém, são apenas duas coisas. Primeiro, que não há qualquer relação causal linear entre eventos críticos (como se desenha a atual pandemia de covid-19) e mudanças sociais progressistas ou emancipatórias. A história, na verdade nos aponta o contrário. Por isso, a segunda certeza que temos é de que o futuro póspandemia que nos aguarda será de intensificação das lutas, mas dificilmente de acúmulo de conquistas. Aparecem no horizonte, com diferentes graus de nitidez, alguns dos temas que continuarão a ser frentes de batalha sob novos contextos - a ainda maior redução de direitos trabalhistas, o aprofundamento dos nacionalismos e regionalismos, a capilarização dos procedimentos de vigilância e controle digital das populações, o revigoramento das fronteiras nacionais, o recrudescimento das violências de gênero ligadas ao espaço doméstico, a atualização das práticas necropolíticas nos territórios de exceção das periferias urbanas, dentre tantos outros pesadelos. Enraizam-se, assim, as desigualdades sócio-espaciais que estruturam os traços que o SARS-CoV-2 risca sobre o globo.

Tais percepções reforçam as dúvidas sobre a efetividade das ações de mitigação dos efeitos letais da covid-19 nos espaços periféricos brasileiros constituintes da maior parte do tecido urbano das principais cidades brasileiras e latino-americana, incluindo as orientações de "isolamento social” (HAESBAERT, 2020b). Não é de se estranhar a falta de políticas emergenciais diferenciadas para essas áreas por parte do Estado (BARBOSA, 2020). Por isso é coerente perguntar-se como se comportarão as diferentes forças políticas que disputam o controle das periferias metropolitanas no contexto de difusão do SARSCoV-2 e intensificação de seus desdobramentos fatais (HAESBAERT, 2020b).

Ainda que seja reconhecidamente cedo para qualquer afirmação, é também inevitável reconhecer que diversos agentes estão atualmente protagonizando ações contundentes nas periferias nestas últimas semanas, das milícias paramilitares ${ }^{38}$ aos grupos ligados ao comércio varejista de drogas ilícitas, passando por instituições religiosas, ONGs e diferentes grupos de ativistas sociais urbanos. A variedade destes últimos se destaca, envolvendo, por exemplo, prevestibulares comunitários, coletivos de comunicadores, frentes locais de mobilização, coletivos culturais, empreendimentos ligados à economia solidária e coletivos de alimentação, em sua imensa maioria iniciativas comunitárias espacializadas, inspiradas muitas vezes naquilo que foi recentemente chamado de política de cuidado (BITETI no prelo) e que têm gerado ações descentralizadas e coordenadas ${ }^{39}$.

As formas de luta que se desenham por esses ativismos são novas? O que podem aprender nessa situação de emergência sanitária? O que conseguem acumular de experiências úteis para o prosseguimento dos combates já travados e para o enfrentamento de possíveis situações futuras? Alguns dos potenciais estão no estreitamento dos laços produzidos por meio do compartilhamento de experiências limítrofes como as de uma pandemia. Ativismos urbanos estão mesclando diferentes formas e frentes de ação, mas o que se destaca parece ser a articulação imbricada entre, por um lado, formas de levantamento de recursos financeiros, coleta e tratamento de dados, produção de materiais informativos e disputa de narrativas empreendidas na dimensão virtual de nosso mundo 
e, por outro, a realização de ações concretas em seus espaços de atuação encharcadas de significados intensos e ligadas explicitamente ao cuidado com o próximo. Nessa relação, o limite do Outro não desaparece, mas é ofuscado pela vivência do risco compartilhado que a coexistência espacial tanto ressalta - e que fica explícita nas ações de distribuição de refeições, de cestas básicas, de produtos de limpeza, de informações, de equipamentos improvisados de higiene, dentre outras atividades. Esse encontro das margens dos sujeitos guarda o potencial de gerar centelhas de identidades coletivas espacializadas, possíveis gérmens de ações coletivas futuras. Poderíamos nos perguntar, por fim, se algo distingue os ativismos urbanos de outros agentes coletivos que têm protagonizando práticas similares. Em meio às diferenças possivelmente existentes há uma particularmente importante para estas páginas: a escalarização das ações desses atores coletivos. As ações emergenciais que estão em plena construção e execução são significadas valendo-se de processos que ocorrem em outros espaços próximos e distantes e em outros momentos passados ou futuros. Apesar de partir da situação imediata de risco e precariedade que unifica todos esses agentes enquanto motivador inicial concreto de suas ações, esses significados a transcendem. Disputá-los obviamente não equivale a salvar vidas, mas compõe o sementário de mundos pós-pandêmicos nos quais precisaremos seguir combatendo - nem que seja para honrar a trajetória de quem, certamente a contragosto, nos deixou ou deixará pelo caminho.

\section{Notas}

1 - Situation Report 51 (OMS, 2020b).

2 - Situation Report 1 (OMS, 2020a); Na, Dingyu, Wenling et al. (2020); Qun, Xuhua, Peng et al. (2020). Dados populacionais retirados do website do governo da cidade (ver: shorturl.at/kJP46).

3 - Grandi (2015, 2016, 2019a, 2019b, 2019c).

4 - Castilho (2020); Melo-Théry e Théry (2020); Algebaile e Oliveira (2020); Roxo (2020).

5 - Sposito e Guimarães (2020); Arrais et al (2020); Pereira (2020); Ramos (2020); Cifuentes-Faura (2020); Monié (2020); Santos (2020); Senna, Herrera e Silva (2020); Rodrigues e Azevedo (2020); Rossi e Silva (2020); Leopoldo (2020); Souza e Ferreira Júnior (2020); Souza Neto e Castro (2020); Rodrigues (2020); Campos (2020); Ribeiro (2020).

6 - Zanotelli e Dota (2020); Haesbaert (2020a; 2020b); Lima (2020); Barbosa (2020); Fortes, Oliveira e Souza (2020); Rocha (2020).

7 - Herod e Wright (2002); MacKinnon (2010).

8 - MacKinnon (2010); Grandi (2015).

9 - “(...) including movement restrictions, closure of schools and businesses, geographical area quarantine, and international travel restrictions."

10 - "Q\&A on coronaviruses (COVID-19)", OMS. Disponível em <shorturl.at/bMPTX> 11 - " (...) the restriction of movement, or separation from the rest of the population, of healthy persons who may have been exposed to the virus, with the objective of monitoring their symptoms and ensuring early detection of cases."

12 - "Coronavírus: 50 entidades lançam o Movimento Reage SC e sugerem ao governo retomada da economia", NSC. 25 de março de 2020. Disponível em: <shorturl.at/frxH7> 13 - "Bolsonaro contraria 157 países ao defender escolas abertas em meio à pandemia", Jornal Folha de São Paulo. 20 de março de 2020. Disponível em: <shorturl.at/eipF8> 14 - Harvey (2020); Castilho (2020); Melo-Théry e Théry (2020); Algebaile e Oliveira (2020); Roxo (2020); Lima (2020); Haesbaert (2020); Porto-Gonçalves (2020a) 
15 - "Os circuitos dos ricos e famosos que disseminaram coronavírus no Brasil", Jornal Folha de São Paulo. 29 de março de 2020. Disponível em: <shorturl.at/yJS04>; "Coronavírus: a rodovia federal que 'levou' a covid-19 para o interior de Pernambuco", BBC News Brasil. 18 de abril de 2020. Disponível em: <https://www.bbc.com/portuguese/brasil-52332235>

16 - Trata-se de reflexão que agrega àquela feita por Lima (2020) ao resgatar as considerações de Edgar Morin sobre a "globalização dos micróbios".

17 - Haesbaert (2020a); Latour (2020).

18 - Latour (2020); Preciado (2020a).

19 - Agamben (2004; 2020a; 2020b).

20 - "Os líderes europeus que estão usando a pandemia para concentrar mais poder", BBC News Brasil. 21 de abril de 2020. Disponível em: $<$ https://www.bbc.com/portuguese/internacional-52358420>

21 - Mbembe $(2003 ; 2020)$.

22 - "The state of broadband 2019: Broadband as a Foundation for Sustainable Development", ITU/UNESCO Broadband Commission for Sustainable Development. Disponível em: <shorturl.at/pBEOZ>

23 - Ver como exemplos: "U.S. government, tech industry discussing ways to use smartphone location data to combat coronavirus", The Washington Post, 17 de março de 2020, disponível em <shorturl.at/bFQ39>; "Governo vai usar dados de operadoras para monitorar aglomeração na pandemia", Jornal Folha de São Paulo, 02 de abril de 2020, disponível em <shorturl.at/cEU08>; "Location Data Says It All: Staying at Home During Coronavirus Is a Luxury", The New York Times, 03 de abril de 2020, disponível em <shorturl.at/ijyA4>; "Coronavirus: Apple and Google team up to contact trace Covid-19", BBC News, 10 de abril de 2020, disponível em <shorturl.at/iCWY4>; "Europa prepara aplicativos de celular para rastrear infectados pelo coronavírus", El País, 15 de abril de 2020, disponível em <shorturl.at/adjR2>; "AI Gets Into The Fight With COVID-19", Forbes, 17 de abril de 2020, disponível em <shorturl.at/bhzU6>; "Plataforma europeia de monitoramento de pessoas ganha força com apoio de governos", Reuters, 17 de abril de 2020, disponível em <shorturl.at/ehwNW>; "Eles sabem quem é você? Entenda o monitoramento de celulares na quarentena", Carlos Affonso em TecFront/UOL, 17 de abril de 2020, disponível em <shorturl.at/fquX8>; "Coronavirus: AI steps up in battle against Covid-19", BBC News, 18 de abril de 2020, disponível em <https://www.bbc.com/news/technology-52120747>; "Como dados sobre sintomas podem ajudar a uma reabertura segura dos países", Mark Zuckerberg em Jornal Folha de São Paulo, 20 de abril de 2020, disponível em: <shorturl.at/aeT69>; "The Pentagon Will Use AI to Predict Panic Buying, COVID-19 Hotspots", Defense One, 22 de abril de 2020, disponível em < shorturl.at/eAEFU>; "Doctors are using AI to triage covid-19 patients. The tools may be here to stay", MIT Technology Review, 23 de abril de 2020, diponível em $<$ shorturl.at/iknuA>.

24 - Dentre tantos exemplos, ver: "O protesto se nega a morrer em meio à pandemia de coronavírus", El País, 15 de abril de 2020, disponível em <shorturl.at/kotz2>; "Bolsonaro é alvo de panelaço em meio a mais um pronunciamento sobre coronavírus", Jornal Folha de São Paulo, 08 de abril de 2020, disponível em <shorturl.at/epsEG>; "Favelas vão à luta: Maré faz vaquinha e Paraisópolis cria área para isolar infectados", Jornal O Globo, 16 de abril de 2020, disponível em <shorturl.at/oFJ89>; "Com Estado 'ausente', favelas se organizam contra COVID-19, violência e desinformação", Sputnik Brasil, 22 de abril de 2020, disponível em <https://sptnkne.ws/Cg6T>. 
25 - Ver, por exemplo: "Como a pandemia de coronavírus impacta de maneira mais severa a vida das mulheres em todo o mundo", G1, 19 de abril de 2020, disponível em <shorturl.at/dGN29>.

26 - Moreira $(2013 ; 2014 ; 2016)$.

27 - Relph (1976) apud Moreira (2013, p. 85).

28 - É importante destacar que há complexidades próprias nos debates conceituais ao redor das características que distinguem teoricamente as concepções de casa, lar, moradia e habitação. Além desses termos, muitas vezes estão a eles associados conceitos como o de família e seus derivados (agregado familiar, núcleo familiar, família nuclear etc.). Meu objetivo aqui não é enveredar por essa senda conceitual, embora ela seja de crucial importância ao aprofundamento dos debates sobre a construção da escala da casa e seus posicionamentos em meio aos arranjos escalares com os quais convivemos cotidianamente e que, por isso, cumprem papel central na construção de nosso mundo. Para mais detalhes sobre esses debates conceituais, ver Moreira $(2013 ; 2014 ; 2016)$.

29 - Sobre alguns dos vários sentidos conceituais e populares da ideia de casa, bem como para uma importante sistematização do campo de estudos que relaciona casa e espaço, ver Blunt e Dowling (2006).

30 - Harvey (2020); Castilho (2020); Sposito e Guimarães (2020).

31 - Ver: "Avanço do coronavírus desafiará cidades mais pobres no interior do Brasil", UOL, 15 de março de 2020, disponível em <shorturl.at/FTV57>; "Coronavírus avança no interior do Brasil e atinge 397 municípios”, Jornal O Globo, 06 de abril de 2020, disponível em <shorturl.at/cgGN7>. Ver também Sposito e Guimarães (2020) e Zorzetto (2020). Cabe lembrar também que estudos clássicos sobre difusão espacial na Geografia também podem trazer ideias potentes às reflexões sobre a atual pandemia, sempre que reavaliados à luz das adequações temporais e espaciais necessárias às teorias e conceitos elaborados nesses estudos. Vale à pena, visando desdobramentos futuros de pesquisa, destacar aqui as contribuições de Hägerstrand (1967) e seus desdobramentos, analisados por exemplo em Blaut (1977) e Cliff e Pred (1992). A geografia têmporo-espacial do geógrafo sueco (HÄGERSTRAND, 1975; 1978a; 1978b; 1983) também pode inspirar de forma relevante as investigações interessadas na circulação e nas interações cotidianas dos indivíduos nesses tempos pandêmicos.

32 - Me inspiro aqui em Mbembe (2019).

33 - Sobre a distinção dessas diferentes escalas do urbano, ver Corrêa (2003; 2011).

34 - São possíveis diversas ponderações sobre o caráter etnocêntrico das definições que orientam os estudos estatísticos a respeito do déficit habitacional brasileiro. Via de regra esse caráter se expressa quando tais concepções tomam como referência modelos derivados de expectativas das classes dominantes a respeito da constituição e do comportamento familiar, bem como das condições materiais que as influenciariam. Não é à toa que a definição daquilo que caracteriza a inadequação habitacional serviu historicamente como justificativa para intervenções estatais que tinham como horizonte (bio)político a redução da multiplicidade de formas de habitar das classes populares, como aponta Moreira (2013; 2014; 2016) sob inspiração de Donzelot (1980). Sobre o assunto, ver também Almeida (2016).

35 - Ver: "Trabalhadoras informais temem não ter como alimentar os filhos em crise do coronavírus", Gênero e Número, 24 de março de 2020, disponível em $<$ shorturl.at/aBR27>; "Como está a visitação nos presídios do Brasil em tempos de isolamento?", Gênero e Número, 07 de abril de 2020, disponível em <shorturl.at/foDG4>; "Grupo de risco em área de risco: Covid-19 torna ainda mais difícil a vida de idosos e doentes crônicos nas favelas e periferias do Rio", Data Labe, 10 de abril de 2020, disponível em <https://datalabe.org/grupo-de-risco-em-area-de-risco/>; "Entre casos 
identificados, covid-19 se mostra mais mortífera entre negros no Brasil, apontam dados", Jornal Folha de São Paulo, 10 de abril de 2020, disponível em <shorturl.at/DE034>; “"Burials Are Cheaper Than Deportations': Virus Unleashes Terror in a Troubled ICE Detention Center", The Intercept, 12 de abril de 2020, disponível em < shorturl.at/bluIK >; "Sem proteção, vendedores desafiam Covid-19 e segurança reforçada em trens da CPTM", Jornal Folha de São Paulo, 12 de abril de 2020, disponível em <shorturl.at/rAMY3>; "Coronavírus: por que a população negra é desproporcionalmente afetada nos EUA?", BBC News Brasil, 13 de abril de 2020, disponível em <https://www.bbc.com/portuguese/internacional-52267566>; "Número de prisões em flagrante por violência doméstica sobe em São Paulo", Universa / UOL, 13 de abril de 2020, disponível em < disponível em <shorturl.at/fsyRU>; "Isolamento social limita acesso de população a tratamento transexualizador no SUS", Gênero e Número, 16 de abril de 2020, disponível em <shorturl.at/ovJY3>; "Epidemia da fome: Insegurança alimentar atinge população vulnerável do RJ", Data Labe, 17 de abril de 2020, disponível em <https://datalabe.org/epidemia-da-fome/>; "Periferia lidera as mortes por coronavírus na cidade de São Paulo, e as mulheres adultas são as mais infectadas", El País, 18 de abril de 2020, disponível em < shorturl.at/bjH35>; "Como a pandemia de coronavírus impacta de maneira mais severa a vida das mulheres em todo o mundo", G1, 19 de abril, disponível em < shorturl.at/bST49>; "Coronavírus: Serviços de saúde cortam contraceptivos quando mulheres mais precisam evitar gravidez", The Intercept Brasil, 20 de abril de 2020, disponível em < shorturl.at/uDU15>; "Vulnerabilidade social é motor da pandemia de Covid-19 em Terras Indígenas, mostra estudo", ISA - Instituto Socioambiental, 22 de abril de 2020, disponível em < shorturl.at/ehjrV>; "Favela na Pressão: Isolamento social, medo da Covid-19 e desemprego castigam saúde mental das periferias", Data Labe, 23 de abril de 2020, disponível em <https://datalabe.org/favela-na-pressao/> .

36 - Haesbaert (2020a) lembra da ideia de "território-abrigo", de Jean Gottman e Milton Santos.

37 - Ver também: "The state in the time of covid-19", The Economist, de 26 de março de 2020, disponível em <shorturl.at/acoPW>.

38 - Ver: "Tráfico e milícia ordenam toque de recolher em favelas do Rio por causa do coronavírus", Jornal Folha de São Paulo, 25 de março de 2020, disponível em $<$ shorturl.at/sxV38>; "Polícia investiga reabertura de comércio a mando de milícia no Rio", UOL, 17 de abril de 2020, disponível em <shorturl.at/crUX8>; "Pesquisa relaciona aumento de covid-19 com atuação de milícias na Baixada Fluminense", Jornal Brasil de Fato, 22 de abril de 2020, disponível em <shorturl.at/boCDJ>.

39 - Ver: "O combate à pandemia covid-19 nas periferias urbanas, favelas e junto aos grupos sociais vulneráveis: propostas imediatas e estratégias de ação na perspectiva do direito à cidade e à justiça social", Fórum Nacional da Reforma Urbana, 24 de abril de 2020, disponível em <shorturl.at/biqIP>.

\section{Bibliografia}

AGAMBEN, Giorgio. Esclarescimentos. (tradução do original publicado em "Quodlibet" em 17 de março de 2020). Acesso em 20 de abril de 2020. Disponível em: $<$ shorturl.at/ekzSX>

AGAMBEN, Giorgio. Estado de exceção. São Paulo: Boitempo. 2004.

AGAMBEN, Giorgio. O estado de exceção provocado por uma emergência imotivada. Instituto Humanitas Unisinos. (tradução do original publicado em "Il Manifesto" de 26 de fevereiro de 2020). Acesso em 20 de abril de 2020. Disponível em: $<$ shorturl.at/bckm6> 
ALMEIDA, Rafael Gonçalves de. Favelas do Rio de Janeiro: a geografia histórica da invenção de um espaço. Tese (Doutorado em Geografia), PPGG/UFRJ. Rio de Janeiro. 2016.

BARBOSA, Jorge Luiz. Por uma quarentena de direitos para as favelas e as periferias!, Espaço e Economia, ano IX, n. 17, pp. 1-4, 2020.

BITETI, Mariane Oliveira. Mulheres e Política do Cuidado em tempos do Covid-19. (no prelo)

BLAUT, James. Two views of diffusion. Annals of the Association of American Geographers, v. 67, n. 3, pp. 343-349. 1977.

BLUNT, Alison; DOWLING, Robin. Home. Londres e Nova York: Routledge. 2006.

CLIFF, Andrew. PRED, Allan. Classics in human geography revisited, Progress in Human Geography, v. 16, n.4, pp. 541-544. 1992.

CORRÊA, Roberto Lobato. Sobre Agentes Sociais, Escala e Produção do Espaço. In: CARLOS, Ana Fani et al. (org): A Produção do Espaço Urbano: Agentes, Processos, Escalas e Desafios. São Paulo: Contexto. 2011.

CORREAA, Roberto Lobato. Uma Nota sobre o Urbano e a Escala. Território, n. 11-1213, pp. 133-136. 2003.

DONZELOT, Jacques. A polícia das famílias. Rio de Janeiro: Graal. 1980.

FOUCAULT, Michel. O Sujeito e o Poder. In: RABINOW, Paul e DREYFUS, Hubert. Michel Foucault. Uma trajetória filosófica. Para além do estruturalismo e da hermenêutica. Rio de Janeiro: Forense Universitária, pp. 231-249. 1995.

FOUCAULT, Michel. Segurança, território e população. São Paulo: Martins Fontes. 2008.

FUNDAÇÃO JOÃO PINHEIRO - FJP. Déficit habitacional no Brasil 2015. Belo Horizonte: FJP; 2018.

GRANDI, Matheus. A construção escalar da ação no movimento dos sem-teto. Tese (Doutorado em Geografia), PPGG/UFRJ, Rio de Janeiro. 2015.

HAESBAERT, Rogério. Desterritorialização sem limites: reflexões geográficas em tempos de pandemia I. Acesso em 22 de abril 2020. Disponível em: <shorturl.at/hnR59> HAESBAERT, Rogério. Reflexões geográficas em tempos de pandemia. Revista Espaço e Economia, ano IX, n. 18, pp. 1-5. 2020 b.

HÄGERSTRAND, Torsten. In search for the sources of concepts. In: BUTTIMER, Anne (ed.). The practice of geography. Essex: Longman. p. 238-257. 1983.

HÄGERSTRAND, Torsten. Innovation diffusion as a spatial process. Chicago: The University of Chicago Press. 1967.

HÄGERSTRAND, Torsten. Note on the quality of life-times. In: CARLSTEIN, Tommy; PARKES, Dom; THRIFT, Nigel (ed.). Timing space and spacing time - Vol. 2: Human activity and time geography. Londres: Edward Arnold. p. 215-224. 1978b.

HÄGERSTRAND, Torsten. Space, time and human conditions. In: KARLQVIST, A. LUNDQVIST, L. SNICKARS, F. (ed.): Dynamic Allocation of Urban Space. Estocolmo: Lexington Books. 1975.

HÄGERSTRAND, Torsten. Survival and arena: on the life-history of individuals in relation to their geographical enviromnet. In: CARLSTEIN, Tommy; PARKES, Dom; THRIFT, Nigel (ed.). Timing space and spacing time - Vol. 2: Human activity and time geography. Londres: Edward Arnold. p. 123-145. 1978a.

HARAWAY, Donna. Saberes localizados: a questão da ciência para o feminismo e o privilégio da perspectiva parcial. Pagu, v. 5, pp. 07-41. 1995.

HARVEY, David. Política anticapitalista em tempos de covid-19. In: DAVIS, Mike et al. Coronavírus e a luta de classes. Terra sem Amos: Brasil. 2020. p. 13-24. 
INSTITUTO BRASILEIRO DE GEOGRAFIA E ESTATÍSTICA - IBGE. Banco de dados: Pesquisa nacional por amostra de domicílios contínua. Brasil. Acesso em 21 de abril de 2020. Disponível em <https://sidra.ibge.gov.br/home/ipca/brasil>.

KILOMBA, Grada. Memórias da plantação: episódios de racismo cotidiano. Rio de Janeiro: Cobogó. 2019.

LATOUR, Bruno. A crise sanitária incentiva a nos prepararmos para as mudanças climáticas. AGB-Campinas. Acesso em 20 de abril de 2020. Disponível em $<$ shorturl.at/eyBEL $>$

MBEMBE, Achille. Bodies as borders. From the European South, n. 4, pp. 5-18. 2019.

MBEMBE, Achille. Necropolitics. Public Culture, n. 15, v.1, pp. 11-40. 2003.

MBEMBE, Achilles. "O direito universal à respiração.” Buala, 9 de abril de 2020. Acesso em 20 de abril de 2020. Disponível em: < shorturl.at/hHJKU>

NA, Zhu; DINGYU, Zhang; WENLING, Wang et al. A Novel Coronavirus from Patients with Pneumonia in China, 2019. The New England Journal of Medice, v. 382, n. 8, 2020, pp. 727-733.

ORGANIZAÇÃO MUNDIAL DA SAÚDE - OMS. Novel Coronavirus (2019-nCov) Situation Report 1 (21 de janeiro de 2020). Disponível em $<$ shorturl.at/bvCKW $>$. Acesso em 22 abr 2020. 2020a.

ORGANIZAÇÃO MUNDIAL DA SAÚDE - OMS. Coronavirus Disease 20019 (COVID-19) Situation Report 51 (11 de março de 2020). Disponível em $<$ shorturl.at/zBFO3>. Acesso em 22 abr 2020. 2020 b.

ORGANIZAÇÃO MUNDIAL DA SAÚDE - OMS. Considerations in adjusting public health and social measures in the context of COVID-19 - Interim guidance (19 de abril de 2020). Disponível em <shorturl.at/ejvRZ>. Acesso em 23 abr 2020. 2020c.

ORGANIZAÇÃO MUNDIAL DA SAÚDE - OMS. Management of ill travellers at Points of Entry (international airports, seaports, and ground crossings) in the context of COVID-19 - Interim guidance (19 de março de 2020). Disponível em $<$ shorturl.at/xFKX9>. Acesso em 23 abr 2020. 2020d.

ORGANIZAÇÃO MUNDIAL DA SAÚDE - OMS. Considerations for quarantine of individuals in the context of containment for coronavirus disease (COVID-19) - Interim guidance (19 de março de 2020). Disponível em < shorturl.at/xATX0>. Acesso em 24 abr 2020. 2020e.

PORTO-GONÇALVES, Carlos Walter. De neoliberais e de keynesianos em tempos de coronavírus. Revista Espaço e Economia, ano IX, n. 18, pp. 1-3. 2020.

PRECIADO, Paul. Aprendiendo del virus. El País, 28 de março de 2020. Disponível em: $<$ shorturl.at/1HTX4>

QUN, Li; XUHUA, Guan; PENG, Wu et al. Early Transmission Dynamics in Wuhan, China, of Novel Coronavirus-Infected Pneumonia. The New England Journal of Medice, v. 382, n. 13, 2020, pp. 1199-1207.

SANTOS, Boaventura de Souza: Um discurso sobre as ciências. São Paulo: Cortez. 2008. SANTOS, Milton. A natureza do espaço. São Paulo: EdUSP. 1996.

SANTOS, Milton. O espaço dividido: os dois circuitos da economia urbana. São Paulo: Edusp. 2008.

SANTOS, Milton. Por uma outra globalização. São Paulo: EdUSP. 2000.

ZIBECHI, Raúl. Coronavírus: a militarização das crises. In.: DAVIS, Mike et al. Coronavírus e a luta de classes. Terra sem Amos: Brasil. 2020. p. 31-33.

ZORZETTO, Ricardo. A segunda onda do coronavírus, Revista Pesquisa Fapesp. 2020. Acesso em 20 de abril de 2020. Disponível em $<$ shorturl.at/ajvCX $>$. 